\author{
Голубьонкова О.О. \\ кандидат економічних наук, доцент \\ E-mail:LegoL72@mail.ru \\ Брайко М.Г. \\ старший викладач \\ кафедра маркетингу, підприємництва і торгівлі \\ Одеська національна академія харчових технологій \\ вул. Канатна, 112, м. Одеса, Україна, 65039 \\ E-mail: Kuzenok1@mail.ru
}

\title{
СТАН КОНКУРЕНЦІЇ НА РОЗДРІБНОМУ РИНКУ АЛКОГОЛЬНИХ НАПОÏB
}

В статті розглянуто основні тенденції у споживанні вина у світі та в Україні. Розглянуто види спеціалізованих торговельних підприємств, що пропонують алкогольну продукцію. Визначено основні сили впливу на них за методикою п'яти конкурентних сил М.Портера та запропоновано стратегію диференціації.

Ключові слова: конкуренція; модель п'яти конкурентних сил; роздрібна торгівля; алкогольні напої; стратегія диференціації.

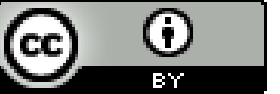

This work is licensed under a Creative Commons Attribution 4.0 International License http://creativecommons.org/licenses/by/4.0/
Постановка проблеми та її зв'язок з важливими науковими та практичними завданнями. Стан сучасного світового ринку вина динамічно змінюється, тому виробники зі всього світу мають вчасно пристосуватися до цих змін задля збереження власної ніші. Це питання є особливо актуальним для вітчизняних виноробів, оскільки, незважаючи на традиції виноробства, які налічують сотні років, їх продукція залишається низько конкурентною не тільки на світовому ринку, а й активно витісняється імпортованою продукцією та фальсифікатами на власному ринку. Підписавши Угоду про асоціацію Україна повністю відкрила свій внутрішній ринок для іноземних виробників вина, які потіснили український продукт. Натомість же українські виробники опинилися сам на сам 3 потужними західними корпораціями. Загострилася ситуація і економічною війною Росії проти України, яка ввела ембарго на українські товари.

Реалізації потенціалу виноробних підприємств має сприяти продумана та обгрунтована конкурентна стратегія, розроблена 3 урахуванням стану ситуації на даному ринку, враховуючі специфіку діяльності роздрібній торгівлі. Важливим також $\epsilon$ вивчення світових тенденцій споживання алкогольної продукції через їх неминучій вплив на вітчизняних споживачів.

Аналіз останніх публікацій 3 проблеми. Проблеми виноробної галузі є об'єктами досліджень у працях таких вчених, як: Гаркуша О.М., Мороз Л. А., Косар Н. С., Купріна Н.М., Осипов В., Агєєва I.М., Каламан О.Б., Данилова Л.Л. та інших, але діяльності саме у сегменті роздрібної торгівлі уваги приділяється недостатньо.
Формування цілей дослідження. Метою статті є дослідження аспектів діяльності та аналізу конкурентного середовища у сегменті роздрібної торгівлі алкогольною продукцією 3 метою вдосконалення розробки маркетингової конкурентної стратегії та обгрунтування напрямів подальших досліджень.

Виклад основних результатів та їх обгрунтування. Проблема розробки та реалізації обгрунтованої конкурентної стратегії, яка відповідає актуальним тенденціям ринку стоїть перед кожним керівником організації. Не менш актуальним є дане питання для організацій, що здійснюють роздрібну торгівлю алкогольною продукцією, а саме - вином. Для розв'язання даної проблеми доцільно використовувати певні маркетингові інструменти, тому що саме маркетинг - це основна функція, яка дозволяє не просто ефективно адаптуватися підприємству до змін у зовнішньому середовищі, а передбачати та навіть впливати на ринкове середовище у власних інтересах.

Серед основних тенденцій світового споживання вина $є$ стабілізація в основних країнах виробниках: Франція, Італія, Іспанія, Португалія, Аргентина, Греція та зростання попиту в країнах, які не є традиційними виробниками вина. У світовому споживанні вина лідерами за даними на 2014 рік є Франція, США, Італія, Німеччина, Китай, Великобританія, Російська Федерація, Іспанія, Аргентина, Румунія, при чому у 2000 році на другому місці по споживанню вина ще була Італія, яка згодом поступилася місцем США. Значно збільшили своє споживання вина порівнюючи із 2000 р. США, Китай, Великобританія, Російська Федерація, у той час як у Франції, Італії, Іспанії, Аргентині споживання вина впало [8]. 
При цьому Франція зберігає світову першість по споживанню вин на душу населення - 52 л у рік. Зниження споживання вина спостерігається й в Італії, другій у світі країні по споживанню вина на душу населення. Разом $з$ тим, споживачі США, займають третій рядок рейтингу, хоча на душу населення в країні припадає тільки 13 л вина. Тоді як Україна перебуває тільки на 84-му місці по споживанню вина на душу населення - 3,64 л [3].

Експерти вважають, що найбільша динаміка зростання ринку в найближчі роки буде відзначатися в Китаї, Росії, Канаді і США [3, 9].

Збільшення продажів вина в цих країнах обумовлений наступними факторами:

- підвищенням культури споживання вина;

- популяризацією здорового способу життя;

- ростом урбанізації населення;

- розвитком туризму;

- знайомством 3 культурами інших народів;

- розвитком енотуризму як способу життя.

Британське агентство Wine Intelligence, що спеціалізується на послугах винного консалтингу й дослідженні ринків, провело дослідження споживчих переваг в області вина, яке показало розбіжності й подібності в смаках покупців у різних країнах. Основна тенденція - споживачі віддають перевагу низькоалкогольним винам. [9]

Якщо жителі таких міст як Лондон, СанФранциско, Берлін і Пекін визначають «ідеальне» вино по-різному, то вони одностайні в перевагах по втримуванню в ньому алкоголю. Споживачі вважають, що його рівень у напої повинен бути нижче, чим пропонований сьогодні більшістю країн-виробників.

Покупці вважають, що місце походження вина є однієї з його самих істотних характеристик. У Китаї 88\% споживачів ставлять цей параметр на перше місце. У Великобританії також думає $71 \%$ опитаних, у Німеччині - 82\%, у США - 74\% [9].

У Китаї, де червоний і золотий кольори вважаються щасливими, четверо 3 п'яти покупців вин віддають перевагу червоним винам. Більш половини населення Німеччини (57\%) віддають перевагу червоним винам. 49\% американців сьогодні роблять вибір на користь червоного вина. Жителі Великобританії, які, як очікувалося, віддадуть пріоритет білим винам, також назвали червоне вино улюбленим. Біле вино на першім місці виявилося лише в 44\% опитаних [9]. Воно зайняло другу позицію в списку вин у Великобританії, Німеччині й США.

Вид винограду вважається одним 3 найважливіших факторів, що визначають вибір вина. Це підтвердило більш 80\% опитаних жителів Великобританії, Китаю й Німеччини. 93\% американців думають також [9]. Чверть споживачів вин з Великобританії назвали Мерло й Пино Гриджіо найбільш кращими напоями. У той час як у США й Китаї найбільшою популярністю користуються вина Каберне, Совиньон і Шардоне. Німці віддають перевагу національним винам Дорнфельдер і Рислінг.

Проведені дослідження показали, що вина 3 закупорювальними пробками більш кращі для жите- лів Німеччини, США й Китаю, тоді як у Великобританії покупці люблять кришки, що закручуються, особливо на пляшках з білим вином.

Вітчизняні виробники здебільшого використовують дані тенденції. Так, компанія «Шабо» розширила експортні кордони i почала експортувати свою продукцію в Китай: високоякісні напівсолодкі вина, наприклад, такі, як «Шабський льох», «Ізабелла», «Червоне Напівсолодке», але китайський дистриб'ютор включив також в експортну заявку широко відомі в Україні сухі вина компанії «Шабо» - «Каберне», «Мерло» і «Сапераві». Експортна історія компанії «Шабо» бере свій початок в 2006 році, коли вперше було здійснено постачання вин «Шабо» в США $[3,6]$.

В Україні поки що позитивних тенденцій щодо споживання вина не спостерігається. У структурі продажів горілка та інші міцні алкогольні напої становлять близько $65 \%$, а вино - $20 \%$. Таке співвідношення зберігається останні кілька років. Через роздрібну мережу реалізується близько 85 \% всієї споживаної продукції, при цьому кіоски займають близько 20 \% від загального числа точок, інші 15\% виробляються і споживаються самостійно або реалізуються «з рук». Так, наприклад, в кожній двадцятій сім'ї виготовляється алкогольна продукція [3].

Офіційної статистики із продажу алкоголю через спеціалізований роздріб немає. Але, на думку директора дистриб'юторської компанії «Витис Груп» Сергія Мазури, на неї доводиться близько $10 \%$ від сумарних продажів алкоголю [3].

Щороку відкривається 10-12 алкогольних магазинів, з яких залишається тільки 3-4, а 70 \% торговельних точок закривається в перший же рік роботи [4].

Спеціалізований роздріб закривається, тому що не витримує конкуренції з великими продовольчими мережами, говорять експерти. «Асортимент алкогольних і великих продовольчих магазинів збігається»,- пояснює Сергій Мазура. Він відзначає, що залучити покупців може асортименти, який на 70$80 \%$ складається з унікальної продукції [3]. Однак продовольчі мережі надають великий вибір алкоголю, і тому спеціалізованим магазинам запропонувати унікальний асортименти непросто.

В 2013 р. закрилась мережа виномаркетів Komilfo, до складу якої входило 3 магазина в Києві. Ще один гравець, який постраждав від існуючої ринкової ситуації та закрився в 2013 р., - це спеціалізований магазин «Шато де вин».

Один з лідерів ринку - мережа магазинів Good Wine розширила свій асортимент за рахунок продуктів харчування й зараз більше працює в сегменті елітних супермаркетів, а не алкогольних магазинів, говорить керуючий партнер консалтингової компанії Retainet Олександр Ланецкий [3].

Асортимент продовольчих ритейлерів буде скорочуватися, впевнений Ланецький. До цього їх буде стимулювати падіння продажів. Олександр Ланецький прогнозує, що коли ритейлери скоротять асортименти у два-три рази, сегмент спеціалізованих 
магазинів почне активно розвиватися.

Спеціалізовані магазини потрібно відкривати поруч із великими продовольчими гипермаркетами, але асортимент такої торговельної точки повинен складатися винятково із власного імпорту, певен генеральний директор мережі Novus Iгор Ланда. Він пояснює, що це дозволяє алкогольному магазину залучити покупців, що приїхали в продовольчий супермаркет, і навпаки [3].

Спеціалізований алкогольний роздріб у нашій країні представлено переважно у форматах виномаркетів і винних бутиків. Головна особливість перших полягає в наявності різноманітного алкоголю за ціною на 20-40\% нижче, ніж у звичайних супермар- кетах. Винні бутики у свою чергу роблять ставку на цінителів напоїв, пропонуючи дорогі марки в основному імпортного продукту. Число гравців у сегменті спеціалізованого алкогольного ритейла за останні п'ять років помітно зросло, хоча їх частка на ринку продажів спиртних напоїв усе ще невелика - 7-10\%. У той же час у європейських країнах на спеціалізований роздріб уже доводиться до 60\% продажів усього алкоголю.

Лідируючими компаніями в українському сегменті виномаркетів є три компанії - «Поляна Україна Груп», «Wine Time» $\mathrm{i}$ «Good Wine»- табл. 1).

Мережі виномаркетів, винні бутіки й магазини в Україні*

\begin{tabular}{|c|c|c|c|}
\hline Назва компанії & $\begin{array}{l}\text { Кількість } \\
\text { міст }\end{array}$ & Назва міста & $\begin{array}{l}\text { Кількість } \\
\text { магазинів }\end{array}$ \\
\hline $\begin{array}{c}\text { Мережа виномаркетів } \\
\text { «Поляна» }\end{array}$ & 10 & $\begin{array}{c}\text { Київ (11), Дніпропетровськ (2), Чернігів, Одеса (2), } \\
\text { Запоріжжя, Полтава, Житомир, Львів, Харків (2), Ми- } \\
\text { колаїв }\end{array}$ & 23 \\
\hline Виномаркети «Wine Time» & 14 & $\begin{array}{c}\text { Київ, Вінниця, Дніпропетровськ, Запоріжжя, Івано- } \\
\text { Франківськ, Луцьк, Львів, Полтава, Рівне, Тернопіль, } \\
\text { Хмельницький, Черкаси, Чернівці, Чернігів }\end{array}$ & 16 \\
\hline Супермаркет «Good Wine» & 2 & Київ, Львів & 3 \\
\hline $\begin{array}{c}\text { Винний супермаркет } \\
\text { «Vintage» }\end{array}$ & 2 & Київ, Дніпропетровськ & 2 \\
\hline Магазин «Wine House» & 1 & Київ & 5 \\
\hline $\begin{array}{c}\text { Винні салони } \\
\text { «In Vino» }\end{array}$ & 1 & Харків & 2 \\
\hline Декан тер «Arlekin» & 1 & Київ & 1 \\
\hline Торговий дім «Вина світу» & 6 & $\begin{array}{c}\text { Дніпропетровськ, Запоріжжя, Мелітополь, Маріуполь, } \\
\text { Одеса }\end{array}$ & 10 \\
\hline Магазини “WINE\&FOOD” & 1 & Київ & 2 \\
\hline Винний бутік «Декантер» & 1 & Київ & 1 \\
\hline Винний бутік «LAVINIA» & 2 & Київ, Одеса & 2 \\
\hline $\begin{array}{c}\text { Винний бутік «Premium } \\
\text { vin» }\end{array}$ & 1 & Херсон & 1 \\
\hline $\begin{array}{l}\text { Фірмовий бутік алкоголь- } \\
\text { них напоїв «АрАрАт» }\end{array}$ & 2 & Київ, Одеса & 3 \\
\hline Магазин «Wine Story» & 2 & Одеса & 3 \\
\hline $\begin{array}{c}\text { Магазин алкогольних } \\
\text { напоїв «Prowine» }\end{array}$ & 1 & Одеса & 1 \\
\hline
\end{tabular}

* власні авторські дослідження

Перевага магазинів цих фірм у порівнянні із класичними супермаркетами в тому, що на полках кожного 3 них презентовано понад двох тисяч. найменувань алкогольних напоїв (в основному імпортне вино).

Винні бутики, як правило, розраховані на невелику кількість покупців. Пропозиція бутиків якісний і недешевий алкоголь, тому цільову аудиторію цих магазинів формують в основному заможні клієнти. Проте, розвиток даного формату утруднене низьким рівнем споживання провина в нашій країні, яке за підсумками минулого року склало 7,4 л на душу населення. Але приводом для оптимізму може служити той факт, що роком раніше українець випи- вав ще менше - 6,6 л [3]. Росту популярності винних бутиків перешкоджає не тільки відсутність платоспроможних покупців, але й необхідність більших капіталовкладень у цей бізнес. Враховуючи високу вартість продукції, закупівля товару є основною статтею витрат.

На українському ринку присутній і формат фірмових магазинів, які відкривають виробники спиртних напоїв. Маючи можливість представити покупцям різноманітний асортименти своєї продукції, виробники можуть знижувати іiі роздрібну вартість. Адже при співробітництві з торговельними мережами націнка на товар звичайно становить 25-30 \%. Успіх фірмового магазину багато в чому залежить 
від сезонності продажів і вдалого місця розташування.

У якості каналу продажів торговці алкоголем усе активніше задіюють інтернет. Як помітив Владимир Коваленко, директор інтернет-магазину MarketA, для споживачів такий формат більш зручний, ніж покупки в торговельних точках. «На сайті можна ознайомитися з усім асортиментами, вибрати товар, який сподобався і оформити заявку. Тут клієнт указує місце й час, коли йому буде зручно одержати замовлення. Найчастіше продукція в онлайн-магазинах дешевше, чим у великих супермаркетах», - пояснює підприємець [3]. Складності торгівлі спиртним через Інтернет, насамперед, викликані вимогами законодавства. Справа в тому, що ліцензія на продаж алкоголю видається тільки при наявності «оффлайнової» точки продажів.

Таким чином, є певні особливості у діяльності роздрібних торгових підприємств, що спеціалізуються на реалізації алкогольної продукції. Без врахування специфіки поведінки покупця, дій основних та потенційних конкурентів, впливу товарів-замінників та постачальників, неможливо розробити актуальну конкурентну стратегію.

Саме через це є особливості розробки моделі п'яти конкурентних сил для ринку вина у сегменті роздрібної торгівлі, запропонованої професором Гарвардської бізнес-школи М.Портером [10]. Розглянемо детально дану методику.

При оцінці сил конкуренції використовується модель М. Портера, що є найбільш розповсюдженим, потужним інструментом для систематичної діагностики основних конкурентних сил, що впливають на ринок, оцінки ступеня впливу кожної з них та визначення характеру конкурентної боротьби на даному ринку [10,12].

Згідно класичної моделі конкурентне середовище формується під впливом таких конкурентних сил, як:

- суперництво між конкуруючими продавцями однієї галузі;

- конкуренція 3 боку товарів, що виробляються фірмами інших галузей, і що є гідними замінниками (субститутами), а також конкурентоспроможні за ціною;

- загроза входу в галузь нових конкурентів;

- економічні можливості та торгівельні спроможності постачальників;

- економічні можливості та купівельні спроможності покупців.

П'ять чинників конкуренції відбивають той факт, що конкуренція в галузі не зводиться лише до гри між підприємствами, що вже закріпилися на ринку. Покупці, постачальники, товари - замінники та претенденти на вхід до галузі - це «конкуренти» підприємства на певному ринку, що відіграють різну роль залежно від обставин.

У моделі М. Портера значення і сила впливу кожного з факторів конкуренції змінюється від ринку до ринку і визначає ціни, витрати, розміри капіталовкладень у виробництво, збут продукції і прибутко- вість бізнесу. Постачальники і покупці, намагаючись використати сприятливу для них ситуацію, знижують прибуток фірми. Конкуренція всередині галузі також знижує прибуток, тому що для підтримки конкурентних переваг доводиться збільшувати витрати (на рекламу, організацію збуту, НДДКР), або втрачати прибуток за рахунок зниження цін. Наявність товарівзамінників зменшує попит і обмежує ціну, яку фірма може запросити за свій товар. 3 погляду вхідних баp'єрів, дія чинників, представлених у моделі, багато в чому визначається, $з$ одного боку, наявністю реальних і потенційних конкурентів, з іншого - перешкодами для входу на ринок. Всі вищезгадані чинники створюють умови для динамічного розвитку конкуренції і «застарівання» наявних конкурентних переваг.

Важливим $є$ зауваження-рекомендація $У$. Бюргерса, що на галузевому рівні дані конкурентні сили майже не можливо контролювати, тоді як «на рівні сегменту їх можливо контролювати або уникати» [11]. Таким чином, обираючи певний сегмент ринку, підприємство може отримати певні конкурентні переваги та досягти необхідного рівня конкурентоспроможності.

Перш ніж розглядати модель М.Портера, визначимо, який «товар» отримує споживач у спеціалізованій торговій точці, купуючи алкогольну продукцію. По-перше - професійну консультацію, по-друге - стабільно широкий асортимент та гарантію наявності улюбленого (іноді ексклюзивного) напою, потретє - гарантію справжності та якості (у тому числі і дотримання умов зберігання). Таким чином, обираючи спеціалізовану торгову точку, споживач отримує додаткові послуги та доповнення до основного товару - вина.

Найбільший вплив здійснюють конкуруючі продавці - спеціалізовані та фірмові магазини, винні бутики, а також спеціалізовані відділи 3 консультантами у великих супермаркетах.

Зростає негативний вплив і з боку товарівзамінників, а саме - спеціалізованих Інтернетмагазинів, в яких передбачено он-лайн консультацію, зручне меню пошуку певного вина, а також додаткову послугу - доставку додому у зручний час.

3 боку споживачів є як негативні тенденції, так і позитивні: зниження купівельної спроможності основної маси населення призводить до більш раціонального витрачання грошей - краще придбати менше вина, але бути впевненим у його якості та доречності. В час, коли не вистачає грошей на великі покупки (авто, меблі тощо, споживачі частіше дозволяють собі певні «маленькі радощі», до яких відноситься i пляшка якісного улюбленого алкогольного напою. Позитивною тенденцією також є зростання популярності вина серед прихильників натуральних, органічних продуктів.

Середній за рівнем вплив відчувається з боку постачальників. По-перше, це необхідність у професійних продавцях-консультантах, сомельє. Сьогодні існує декілька професійних шкіл та достатньо різних курсів 3 підготовки даних фахівців. Певною пробле- 
мою залишається їх високий рівень оплати праці. Крім того, у зв'язку з тим, що більшу частину асортименту складає імпортна продукція, досить важко забезпечувати стабільність асортименту.

Рівень загрози появи нових конкурентів ми оцінюємо як низький через необхідність інвестувати немаленькі суми на закупівлю товару 3 невисоким рівнем оборотності (вино не є продуктом першої необхідності, і відповідно, товаром щоденної купівлі).

Таким чином, найбільш доцільною буде конкурентна стратегія диференціації. Стратегію диференціації доцільно реалізовувати шляхом додавання додаткових послуг: створення лекторію, консультації лікаря-дієтолога, організація енотурів, екскурсій на виробництво (через партнерську програму з туристичними агенціями), святкове оформлення покупки тощо.

Висновки та перспективи подальших досліджень. Отже, можна назвати такі основні тенденції на світовому ринку вина:

- $\quad$ світовий ринок вина $є$ високо конкурентним ринком, при чому на арену все впевненіше виходять експортери 3 країн Нового Світу, у той час як доля традиційних експортерів вина на світовому ринку скорочується;

- у світовому споживанні вина існує тенденція до незначного зростання; при цьому у країнах, де споживання вина пов'язано із багатовіковою традиці$€ ю$ воно має тенденцію до скорочення, у той час як обсяги споживання вина у Китаї, США, Великобританії, Росії збільшуються;

- споживачі більшості країн як і раніш віддають перевагу винам Старого Світу (Франція, Італія,
Австрія, Литва, Чехія, Бельгія, Швейцарія, Норвегія, Росія й ін.), зростає кількість країн, в яких першість вин Старого Світу вже не така переконлива (Німеччина, Нідерланди, Фінляндія, Великобританія, Данія, Канада, США, Мексика, Китай, Японія, Гонконг) та є країни, де споживачі віддають превагу винам Нового Світу (Ірландія, Австралія, Бразилія);

- $\quad$ наразі продовжується традиційна для світового ринку вина ситуація перевиробництва, але серед вітчизняних виробників вина є підприємства, що активно збільшують експорт своєї продукції.

В Україні структурних змін у бік алкогольних напоїв 3 невисоким вмістом спирту не спостерігається. Більшість алкогольної продукції реалізується через роздрібну торгівлю, а саме - продовольчі супермаркети. На ринку активно діють спеціалізовані роздрібні торговельні підприємства 3 продажу алкогольних напоїв: фірмові магазини виробників, виномаркети, винні бутики, але вони відчувають сильний вплив 3 боку великих супермаркетів та товарівзамінників - он-лайнових магазинів.

Найбільш доцільною в таких умовах є стратегія диференціації, яка полягає у наданні споживачам додаткових послуг.

Таким чином, за допомогою певних маркетингових інструментів можливим стає розробка обгрунтованої стратегії та її ефективна реалізація.

Перспективою подальших досліджень є розробка механізму моніторингу споживацьких переваг щодо вина та процесу його купівлі, а також методики впровадження елементів крос-маркетингу.

\section{Література}

1. Гаркуша О.М. Проблеми розвитку виноградарсько-виноробного підкомплексу України [Текст] / O. Гаркуша // Економіка АПК. - 2008. - № 11. - С.3-5.

2. Мороз Л.А. Дослідження Українського ринку горілчаної продукції та удосконалення маркетингової комунікаційної політики їі регіональних виробників [Електронний ресурс] / Мороз Л.А., Косар Н.С., Кузьо Н.Є. // Ефективна економіка. - Режим доступу: http://www.economy.nayka.com.ua/?op=1\&z=4838

3. Осипов В. Виноградарство та виноробство України. Сучасний стан, проблеми, тенденції розвитку / В.Осипов, Л. Осипова // Економіст. - 2015. - № 5. - С. 28-31

4. Купріна Н.М. Ефективність діяльності підприємств харчової промисловості Одеської обл.: практичний аспект / Н.М. Купріна, Х.О. Баранюк // Економіка харчової промисловості. - 2015. - Т. 7, Вип.4. - С. 28-34. - doi: 10.15673/2312-847x.4/2015.56732

5. Каламан О.Б. Аналіз стану та особливості управління підприємствами виноградарсько-виноробного під комплексу / О.Каламан // Економіка харчової промисловості. - 2015. - Т. 7, Вип.4. - С. 40-44. - doi: $10.15673 / 2312-847 x .4 / 2015.56740$

6. Ткаченко О.Б. Інноваційні складові стратегічного розвитку виноробних підприємств України / Ткаченко О.Б., Агеєва І.М., Беркгаут В.М. // Економіка харчової промисловості. - 2016. - Т. 8, Вип.1. - С. 55-61. doi: $10.21691 /$ fie.v8i1.66

7. Данилова ЛЛ Оптимізація асортиментної політики вітчизняних торговельних підприємств // Вісник ДонДУЕТ. - 2001. - №4(12 ) - С.192-196

8. Le Ann A. Fickle, Raymond J. Folwell, Trent Ball, Carter Clary. Small Winery Investment and Operating Costs Extension Bulletin // [Електронний pecypc]. - Режим доступу: http://cru.cahe.wsu.edu/CEPublications/eb1996/eb1996.pdf 
9. OIV (International Organisation of Vine and Wine). - 2015p. [Електронний ресурс]. - Режим доступу: http://www.oiv.int/oiv/cms/index

10. Porter, M. E. Competitive Strategy: Techniques for Analyzing Industries and Competitors. New York: Free Press, 1980. (Republished with a new introduction, 1998.)

11. Burgers W. Marketing Revealed: Challenging the Myths. Hardcover, 200 pages Published January 15th 2008 by Palgrave Macmillan

12. Aaker David A. Strategic Market Management. Wiley, 2013. - 336 p.

13. Henry Mintzberg, Joseph B. Lampel, James Brian Quinn, Sumantra Ghoshal The Strategy Process: Concepts, Context, Cases. Prentice Hall,2002. - 489 p.

Стаття надійшла 15.08.2016

Стаття прийнята до друку 29.08.2016

Доступно в мережі Internet 30.09.2016

Голубёнкова Е.А.

кандидат экономических наук, доцент

E-mail:LegoL72@mail.ru

Брайко М.Г.

старший преподаватель

кафедра маркетинга, предпринимательства и торговли

Одесская национальная академия пищевых технологий

ул. Канатная, 112, г. Одеса, Украина, 65039

E-mail: Kuzenok1@mail.ru

\section{СОСТОЯНИЕ КОНКУРЕНЦИИ НА РОЗНИЧНОМ РЫНКЕ АЛКОГОЛЬНЫХ НАПИТКОВ}

В статье рассмотрены основные тенденции в потреблении вина в мире и в Украине. Целью статьи является исследование аспектов деятельности и анализ конкурентной среды в сегменте розничной торговли алкогольной продукцией с целью совершенствования разработки маркетинговой конкурентной стратегии и обоснование направлений дальнейших исследований.

Исследование позволило выявить следующие тенденции: мировой рынок вина является высоко конкурентным рынком; увеличиваются объемы потребления вина в Китае, США, Великобритании, России; продолжается традиционная для мирового рынка вина ситуация перепроизводства, но среди отечественных производителей вина есть предприятия, активно увеличивающие экспорт своей продукции.

В Украине структурных изменений в сторону алкогольных напитков с низким содержанием спирта не наблюдается. Большинство алкогольной продукции реализуется через розничную торговлю, а именно - продовольственные супермаркеты. На рынке активно действуют специализированные розничные торговые предприятия по продаже алкогольных напитков: фирменные магазины производителей, виномаркеты, винные бутики, но они испытывают сильное влияние со стороны крупных супермаркетов и товаров-заменителей - онлайновых магазинов.

В таких условиях наиболее целесообразной будет стратегия диффреренциации, которая заключается в предоставлении потребителям дополнительных услуг.

С помощью определенных маркетинговых инструментов возможным становится разработка обоснованной стратегии и ее эффективная реализация.

Перспективой дальнейших исследований является разработка механизма мониторинга потребительских предпочтений в отношении вина и процесса его покупки, а также методики внедрения элементов кросс-маркетинга.

Ключевые слова: конкуренция; модель пяти конкурентных сил; розничная торговля; алкогольные напитки; стратегия дифференциации. 


\author{
Golubyonkova 0. \\ Ph.D. in Economics, Associate Professor \\ E-mail:LegoL72@mail.ru \\ Braiko M. \\ Assistant \\ Department of of Marketing, Business and Trade \\ Odessa National Academy of Food Technologies \\ Kanatna str., 112, Odessa, Ukraine, 65039 \\ E-mail: Kuzenok1@mail.ru
}

\title{
COMPETITIVE SITUATION IN THE RETAIL MARKET OF ALCOHOLIC BEVERAGES
}

In article the main tendencies in consumption of wine in the world and in Ukraine are considered. The purpose of article is the research of aspects of activities and the analysis of a competitive environment in a segment of retail trade by alcoholic products for the purpose of enhancement of development of marketing competitive strategy and reasons for the directions of further researches.

The research allowed to reveal the following tendencies: the world market of wine is highly competitive market; amounts of consumption of wine in China, the USA, Great Britain, Russia increase; the excess production situation, traditional for the world market of wine, proceeds, but among domestic manufacturers of wine there are entities which are actively increasing export of the products.

In Ukraine of structural changes towards alcoholic beverages with low content of alcohol it isn't observed. The majority of alcoholic products is sold through retail trade, namely - food supermarkets. Specialized retail trade enterprises selling alcoholic beverages actively operate on the market: corporate shops of producers, vinomarketa, wine boutiques, but they are strongly influenced from large supermarkets and goods substitutes - on-line shops.

In such conditions of the most reasonable there will be a strategy of differentiation which consists in provision to consumers of additional services.

By means of certain marketing tools possible is a development of reasonable strategy and its effective implementation.

Prospect of further researches is development of the mechanism of monitoring of consumer preferences concerning wine and process of its purchase, and also a technique of implementation of elements of cross-marketing.

Keywords: competition; model of five competitive forces; retail trade; alcoholic beverages; strategy of differentiation.

\section{References}

1. Harkusha, O. M. (2008). Problemy rozvytku vynohradarsko-vynorobnoho pidkompleksu Ukrainy. Ekonomika APK, 11, 3-5.

2. Moroz, L. A. (2014). Moroz L.A. Doslidzhennia Ukrainskoho rynku horilchanoi produktsii ta udoskonalennia marketynhovoi komunikatsiinoi polityky yii rehionalnykh vyrobnykiv. Retrieved 2016, from http://www.economy.nayka.com.ua/?op=1\&z=4838

3. Osypov, V., \& Osypova, L. (2015). Vynohradarstvo ta vynorobstvo Ukrainy. Suchasnyi stan, problemy, tendentsii rozvytku. Ekonomist, 5, 28-31.

4. Kuprina, N. M. (2015). Efektyvnist diialnosti pidpryiemstv kharchovoi promyslovosti Odeskoi obl.: Praktych-nyi aspekt / , Kh.O. Baraniuk. Ekonomika Kharchovoi Promyslovosti, 4(7), 28-34. doi:10.15673/2312$847 \mathrm{x} .4 / 2015.56732$

5. Kalaman, O. B. (2015). Analiz stanu ta osoblyvosti upravlinnia pidpryiemstvamy vynohradarskovynorobnoho pid kompleksu. Ekonomika Kharchovoi Promyslovosti, 4(7), 40-44. doi:10.15673/2312$847 \mathrm{x} .4 / 2015.56740$

6. Tkachenko, O. B., Aheieva, I. M., \& Berkhaut, V. M. (2016). Innovatsiini skladovi stratehichnoho rozvytku vynorobnykh pidpryiemstv Ukrainy. Ekonomika Kharchovoi Promyslovosti, 1(8), 55-61. doi: 10.21691/fie.v8i1.66 
7. Danylova, L. L. (2001). Optymizatsiia asortymentnoi polityky vitchyznianykh torhovelnykh pidpryiemstv. Visnyk DonDUET, 4(12), 192-196.

8. Fickle, L. A., Folwell, R. J., Ball, T., \& Clary, C. (1996). Small Winery Investment and Operating Costs Extension Bulletin. Retrieved 2016, from http://cru.cahe.wsu.edu/CEPublications/eb1996/eb1996.pdf

9. OIV (International Organisation of Vine and Wine). - 2015r. (2015). Retrieved 2016, from http://www.oiv.int/oiv/cms/index

10. Porter, M. E. (1980). Competitive Strategy: Techniques for Analyzing Industries and Competitors. New York: Free Press.

11. Burgers, W. (2008). Marketing Revealed: Challenging the Myths. Hardcover: Palgrave Macmillan.

12. Aaker, D. A. (2013). Strategic Market Management. Wiley.

13. Mintzberg, H., Lampel, J. B., \& Quinn, J. B. (2002). Sumantra Ghoshal The Strategy Process: Concepts, Context, Cases. Prentice Hall.

Received 15 August 2016

Approved 29 August 2016

Available in Internet 30.09.2016 